\title{
SIMPLIFIED ANALYTICAL MODEL OF THE FORCE ACTION OF AN ION BEAM ON A SPHERE
}

\author{
Institute of Technical Mechanics \\ of the National Academy of Sciences of Ukraine and the State Space Agency of Ukraine \\ 15 Leshko-Popel St., Dnipro 49005, Ukraine; e-mail: maslova_anjyta@mail.ru, I_anjyta@bigmir.net
}

The aim of this paper is to construct a simplified analytical model of the force action of an ion beam on a sphere. The problem under consideration is topical in connection with the development of a contactless method for deorbiting large space debris objects by acting on them with an ion beam generated onboard a dedicated spacecraft. Assuming the Gaussian distribution of the ion density in the beam, expressions were constructed for determining the force action on the target (solid body) in the general case. For a spherical target, it was shown that the force transmitted by the ion beam to the target lies in the plane formed by the beam symmetry axis and the radius vector of the center of the sphere relative to the beam exit point. Analytical estimates were constructed for the force transmitted to the sphere in the case where the center of the sphere lies on the beam symmetry axis. This simplified analytical model offers a better insight into beam-to-target force transfer and provides conditions for the synthesis of active satellite - target relative motion control laws and for analytical estimation of their efficiency.

\section{Keywords force action of an ion beam, ion beam, sphere.}

1. Liou J. C., Johnson N. L. A sensitivity study of the effectiveness of active debris removal in LEO. Acta Astronautica. 2009. V. 64, No. 2. Pp. 236-243.

2. Jakhu R. S., Nyampong Y. M., Sgobba T. Regulatory framework and organization for space debris removal and on orbit servicing of satellites. Journal of Space Safety Engineering. 2017. V. 4, Issue 3. Pp. 129-137.

3. Pearson J., Carroll J., Levin E., Oldson J. EDDE: ElectroDynamic Debris Eliminator For Active Debris Removal. International Conference on Orbital Debris Removal (December 8-10, 2009). URL: http://www.startech-inc.com/papers/edde_for_debris_conference.pdf.

4. United Nations' website. Space Debris Mitigation Guidelines of the Committee on the Peaceful Uses of Outer Space URL: http://www.un.org/ru/documents/decl_conv/conventions/space_debris.shtml.

5. Yuzhnoye State Design Office's website. Space Debris Mitigation. Active and Passive Systems (in Russian). URL: http://www.yuzhnoye.com/technique/innovative-technologies/space-debris/.

6. LEOSWEEP: Improving Low Earth Orbit Security With Enhanced Electric Propulsion. URL: http://www.leosweep.upm.es.

7. Bombardelli C., Alpatov A. P., Pirozhenko A. V. et al. Ion beam shepherd project. Ideas and problems (in Russian). Kosmichna Nauki I Tehnologia. 2014. V. 20, No. 2. Pp. 55-60.

8. Alpatov A., Cichocki F., Fokov A., Khoroshylov S., Merino M., Zakrzhevskii A. Determination of the force transmitted by anion thruster plasma plume to an orbital object. Acta Astronautica. 2016. No. 119. Pp. 241251.

9. Cichocki F., Merino M., Ahedo E. Modeling and Simulation of EP Plasma Plume Expansion into Vacuum, 50th AIAA/ASME/SAE/ASEE Joint Propulsion Conference. AIAA Propulsion and Energy Forum. 2014. No. 3828.17 pp.

10. Beal B. E., Gallimore A., Haas J. M., Hargus W. A. Plasma properties in the plume of a hall thruster cluster. Journal of Propulsion and Power. November-December 2004. V. 20, No. 6. Pp. 985-991.

11. Bombardelli $\therefore$ Ion beam technology for space debris mitigation. URL: http://sdg.aero.upm.es/PUBLICATIONS/PDF/2017/Bombardelli_VKI_LS_IBS.pdf 